\title{
Local Circulation Features in the Eastern Amazon: High-resolution Simulation
}

\author{
Michell Fontenelle Germano ${ }^{1, *}$, Marcos Daisuke Oyama²
}

Germano MF iD https://orcid.org/0000-0002-6869-4024

Oyama MD (D) https://orcid.org/0000-0001-8720-912X

\section{How to cite}

Germano MF; Oyama MD (2020) Local Circulation Features in the Eastern Amazon: High-resolution Simulation J Aerosp Tecnol Manag, 12: e0820. https://doi.org/10.5028/jatm. v12.1100

\begin{abstract}
A high-resolution simulation of a real case is carried out in Eastern Amazon (Northeastern coast of State of Pará) with the Weather Research and Forecasting (WRF) model in order to analyze/detect local circulation features in the region. To this end, we simulated a case with low interference of synoptic weather systems and precipitation aiming to eliminate the effects of convective systems in local circulations. The performance of the model for the day studied was evaluated and the existence of circulations found in the simulation was confirmed through observational data. The model performance evaluation showed that the model was able to capture most of the patterns for the studied area. The simulation captured the presence of three main circulations: the Sea Breeze (SB), on the coast; the Land Breeze (LB), also on the coast; and the Bay Breeze (BB), which forms on both banks of Marajó Bay. In addition to these three major circulations, the high-resolution simulations also revealed the presence of a river breeze (RB) from Guamá River and a fan-shaped circulation on the entrance of Guajará Bay. The observational data confirmed the presence of Guamá River breeze from the Southeast, which is more active from July to September.
\end{abstract}

KEYWORDS: Breeze circulation, Local circulation, Eastern Amazon, High-resolution simulation, Weather Research and Forecasting.

\section{INTRODUCTION}

The breeze circulation is one of the most well-known meteorological phenomena in literature, being classified on the mesoscale according to Orlanski (1975). The knowledge regarding said phenomenon is sufficiently extensive, with records dating no earlier than a thousand years ago (Simpson 1994). Weather and climate in tropical South America is modulated by many of these circulations (Silva-Dias et al. 2004; Santos 2017; Oliveira and Fitzjarrald 1993; Oliveira and Fitzjarrald 1994). The region comprising the Western coast of State of Maranhão, which includes Alcântara Launch Center (CLA) region, and the Northeastern coast of State of Pará, in Eastern Amazon (see Fig. 1 for geographical location of the target area in this study), has an even more complex system of local circulations, affecting weather and climate in the region due to the presence of numerous bays, rivers, lakes, and the Atlantic Ocean (Souza Filho 2005). These conditions create the perfect environment for formation of local circulations, which only need differential heating between two different surfaces and are driven by a horizontal pressure gradient (Simpson 1994; Miller et al. 2003).

Although these circulations are easy to identify, detecting them can be quite challenging in regions with complex geomorphology, such as Eastern Amazon. An example of these difficulties can be found in Souza and Oyama (2017), in which was not possible to precisely define the breeze potential in the region due to the complex and intense local circulation patterns. Germano et al. (2017)

1.Instituto Nacional de Pesquisas Espaciais - Departamento de Meteorologia - São José dos Campos (SP), Brazil.

2.Departamento de Ciência e Tecnologia Aeroespacial - Instituto de Aeronáutica e Espaço - Divisão de Ciências Atmosféricas - São José dos Campos (SP), Brazil.

*Correspondence author: michellfgermano@gmail.com,

Received: Nov. 12, 2018 | Accepted: Jun. 24, 2019

Section Editor: Rosa Marques 
were able to observationally identify the main circulation patterns in localities of the region. However, some local circulations are still hidden in the main circulations signal. For instance, Wanzeler (2018), in a recent study of the region, found a complex pattern of local circulations, which he attributed to local and/or regional factors.

One way to identify these local circulation patterns is through high resolution simulations in numerical models. Although we lack this type of study in the Eastern Amazon, there are some examples of numerical simulations that can identify local circulations. Matos and Cohen (2016), using Brazilian developments on the Regional Atmospheric Modeling System (BRAMS), with 1 km of horizontal spacing, detected the presence of a system that forms on the Eastern margin of Marajó Bay due to BB coming from the bay. This system was named Microlinha de Instabilidade Fluvial (MIF) and is marked by a phase change from South to North between 17 and 21 UTC, indicating the onset of the air that comes from Marajó Bay in the region.

Wanzeler (2018) found the main breeze patterns that operate on Belém-PA and Alcântara-MA during the dry season of the region (September-October-November) with numerical simulations in WRF model with horizontal spacing of $3 \mathrm{~km}$. The author observed the presence of BB (from Marajó Bay) and coastal breeze (maritime and terrestrial). In Belém, BB had its onset between 13 and 17 UTC, with a significant change in the direction of the wind. The presence of a stationary cloudiness over Belém was associated with the possible effects of adjacent water bodies. In addition, centers of divergence and convergence were found in the simulations, affecting the transition from LB (night) to SB (day).

These studies are two of the few examples of numerical simulations used for detection of local circulations in the region; both of them were able to capture the main circulation patterns. However, some local circulations (in the order of meters to a few kilometers) could not be identified due to the horizontal resolution used in these simulations ( $1 \mathrm{~km}$ and $3 \mathrm{~km}$ ), which does not obtain certain aspects of smaller circulations, given the size of some water bodies (sometimes less than $1 \mathrm{~km}$ in width). In other parts of Amazon rainforest, we have some examples of high-resolution simulations. Silva-Dias et al. (2004), using Regional Atmospheric Modeling System (RAMS) with a horizontal spacing of $2 \mathrm{~km}$, detected the presence of a RB in Santarém, a city located at the confluence of Tapajós and Amazon Rivers. The presence of a double cell on Amazon River and a single cell on Tapajós River, both occurring during the day, was observed. Lu et al. (2005), also using RAMS with horizontal spacing of $1 \mathrm{~km}$ for studying Santarém, investigated mesoscale circulations and variations of $\mathrm{CO}_{2}$ through numerical simulations. The authors detected the presence of low-level convergence zones, forming on the east bank of Tapajós River even in situations of intense trade winds. Santos (2017), in numerical simulations for Manaus, using Ocean-Land-Atmosphere Model (OLAM) with a horizontal spacing of $780 \mathrm{~m}$, found that local circulations are also modulated by seasonal floods, which happen in the region, directly affecting its propagation and formation.

Questions regarding local circulation features in a region with complex geomorphology such as Eastern Amazon are still open. In this sense, this study aims to identify the main circulations patterns in the region, through a real case high-resolution simulation (300 $\mathrm{m}$ in innermost domain) in WRF model for June $18^{\text {th }}, 2011$.

\section{DATA AND METHODOLOGY}

\section{STUDY AREA}

The study area comprises the largest city in Brazilian Eastern Amazon (Fig. 1), Belém-PA (population: 1,393,399). This city is located alongside Guajará Bay, with marked urban development, and is approximately $100 \mathrm{~km}$ from the coast. According to Souza Filho (2005), the Northeastern coast of State of Pará is composed of numerous bays, which are found in the majority of the coastline, until it meets Marajó Bay. The terrain becomes even more complex near Belém, where we have two large bays (Marajó and Guajará) and the Guamá River to the South of the city. Marajó Bay is the largest bay near the city, whose Western part is surrounded by Guajará Bay. 


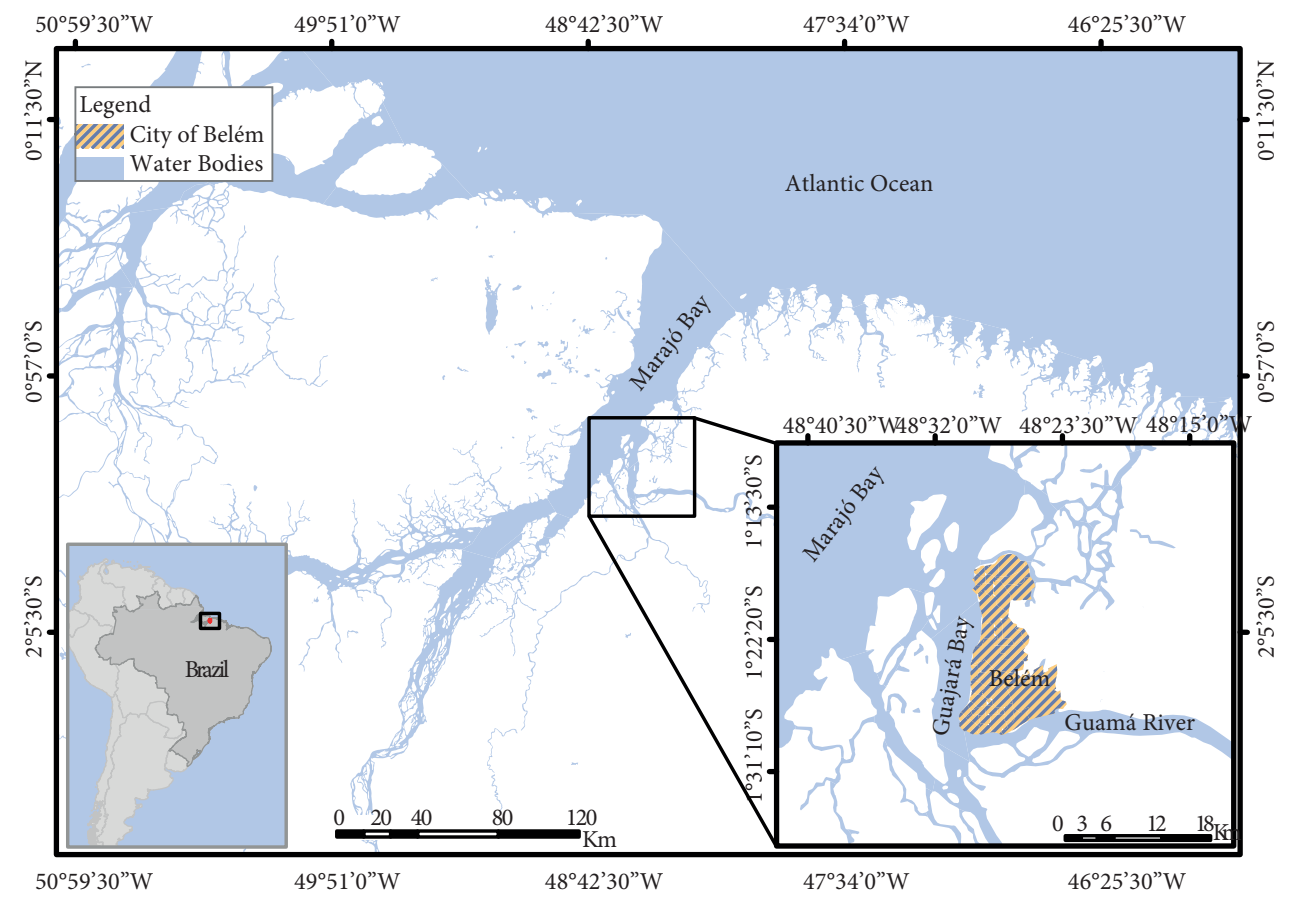

Figure 1. Map of the study area.

\section{NUMERICAL SIMULATIONS}

The numerical model used in this study was WRF model v. 3.9.1.1. A detailed description of the model's operation can be found in Skamarock et al. (2008). Four nested grids were used in the simulations (Fig. 2): the first with horizontal spacing of $9 \mathrm{~km}$ and $71 \times 70$ grid points; the second with spacing of $3 \mathrm{~km}$ and $88 \times 91$ grid points; the third with spacing of $1 \mathrm{~km}$ and $91 \times 97$ grid points; and a more refined grid centered over Belém with horizontal spacing of $0.3 \mathrm{~km}$ and $148 \times 160$ grid points. The number of vertical levels was $45 \mathrm{in}$ all grids. The time step was $5 \Delta \mathrm{x}(45 \mathrm{~s})$, as recommended by Wei et al. (2017), and there was an integration time of $60 \mathrm{~h}$ (starting in June $17^{\text {th }}, 2011$, at 00 UTC, and finishing in June 19 ${ }^{\text {th }}, 2011$, at 12 UTC). Initial and boundary conditions were obtained from ERA 5 reanalysis with horizontal spacing of $0.25^{\circ}$ and hourly estimates (Hersbach and Dee 2016). The first $12 \mathrm{~h}$ were discarded as spin-up. The parameterizations used in the simulations are shown in Table 1; the choice of parameterizations was based on Oliveira (2017). Cumulus parameterization was only used on outermost domain ( $9 \mathrm{~km})$. For detection and analysis of different types of local circulations, the domains used in this study were the following: Domain $2(3 \mathrm{~km})$, Domain $3(1 \mathrm{~km})$, and Domain $4(300 \mathrm{~m})$. The simulations were conducted for June $18^{\text {th }}, 2011$, date chosen, for simplicity, due to the absence of synoptic systems and low precipitation in the region. The analyses consist of three transects (Fig. 3), two of which are positioned in the zonal direction and one in the meridional direction. With these transects, we expected to analyze and evaluate the different types of local circulations operating in the region. Near the coast, transect $\mathrm{AB}$ has a main goal to evaluate $\mathrm{SB}$ and $\mathrm{LB}$; transect $\mathrm{CD}$ is expected to evaluate the changes caused in BF; finally, with transect EF, we expect to evaluate the influence of the RB from Guajará Bay and other smaller local circulations that operate in the region.

\section{MODEL PERFORMANCE EVALUATION AND OBSERVATIONAL DATA}

For evaluating the model performance, data were retrieved from Instituto Nacional de Meteorologia (INMET) for $2 \mathrm{~m}$ temperature and wind (direction and speed) at $10 \mathrm{~m}$. The places chosen for evaluation were: Belém $\left(-1.4103^{\circ} ;-48.4383^{\circ}\right)$, Castanhal 


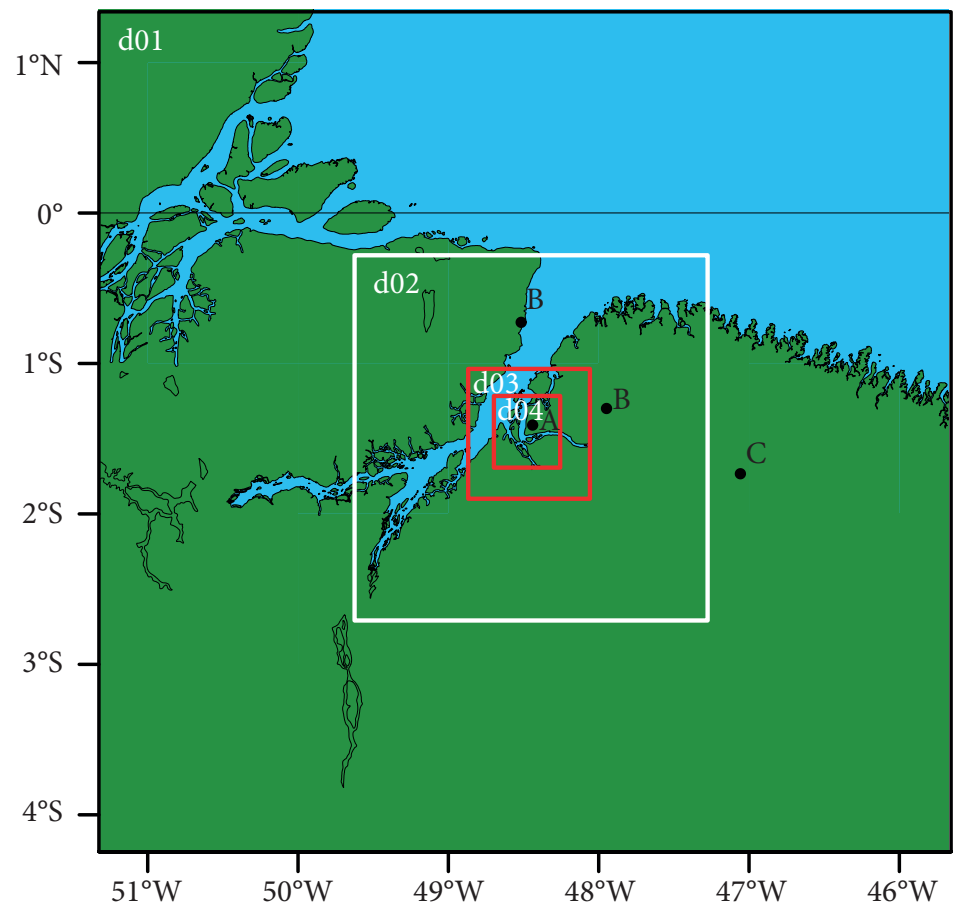

Figure 2. Domains of the model grids. The points marked on the map refer to the automatic weather stations used for the model performance evaluation, corresponding to: "A", Belém; "B", Castanhal; "C", Capitão Poço; and "D", Soure.

Table 1. Parameterizations used in the numerical simulation.

\begin{tabular}{|c|c|c|}
\hline Parameterization & Schemes & References \\
\hline Micro Physics & $\begin{array}{l}\text { WRF Single-Moment 3-class scheme } \\
\text { (WSM3). }\end{array}$ & (Hong et al. 2004; Hong et al. 1998) \\
\hline Longwave Radiation & $\begin{array}{c}\text { RRTM scheme: Rapid Radioactive } \\
\text { Transfer Model. }\end{array}$ & (Mlawer et al. 1997) \\
\hline Shortwave Radiation & Dudhia scheme. & (Dudhia 1989) \\
\hline Surface Layer & MM5 Similarity Scheme. & $\begin{array}{c}\text { (Beljaars 1995; Dyer and Hicks 1970; } \\
\text { Paulson 1970; Webb 1970; Zhang and } \\
\text { Anthes 1982) }\end{array}$ \\
\hline Land Surface & Noah-MP Land Surface Model. & $\begin{array}{l}\text { (Guo-Yue et al. 2011; Zong-Liang et al. } \\
\text { 2011) }\end{array}$ \\
\hline Planetary Boundary Layer & Yonsei University Scheme (YSU). & (Hong et al. 2006) \\
\hline Cumulus Physics & Kain-Fritsch Scheme. & (Kain 2004) \\
\hline
\end{tabular}

$\left(-1.2952^{\circ} ;-47.9281^{\circ}\right)$, Capitão Poço $\left(-1.7489^{\circ} ;-47.0614^{\circ}\right)$, and Soure $\left(-0.8112^{\circ} ;-48.5158^{\circ}\right)$. The satellite images were retrieved from Centro de Previsão de Tempo e Estudos Climáticos (CPTEC).

The analyses of the data were made for $24 \mathrm{~h}$ on June $18^{\text {th }}$ until 12 UTC of the next day (June $19^{\text {th }}$ ). For model performance evaluation purposes, $\mathrm{mE}$ (mean error, or bias), mAE (mean absolute error), and RMSE (root mean square error) were calculated. The region lacks surface weather stations, so it was necessary to use stations that cover different grid domains (see Fig. 2 for geographical location of weather stations used in model evaluation). Only the domain of higher spatial resolution was used for each locality to analyze static errors (Clarke and Cooke 1978). In order to confirm the presence of RB from Guamá River, for Belém in particular, a dataset of wind (direction and speed) from 2003 to 2013 was analyzed to calculate the monthly hourly anomaly. 
(a)

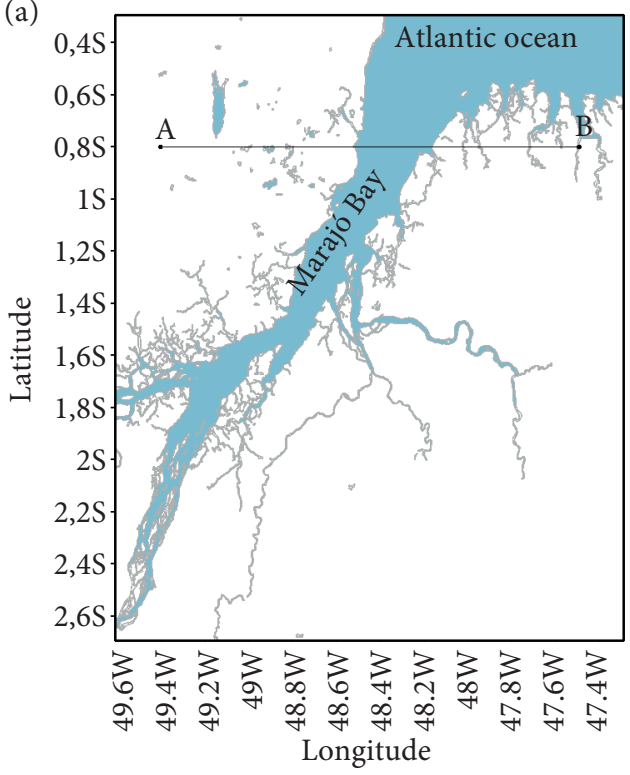

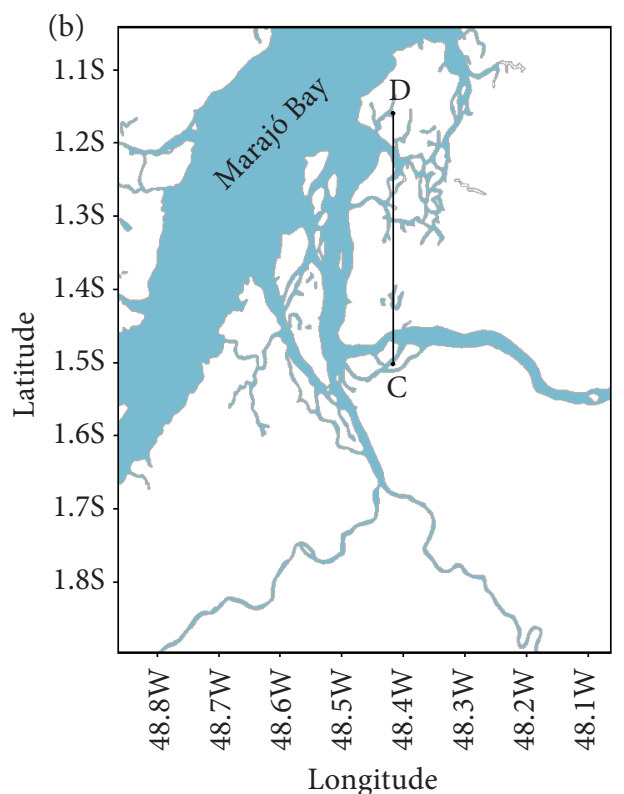

(c)

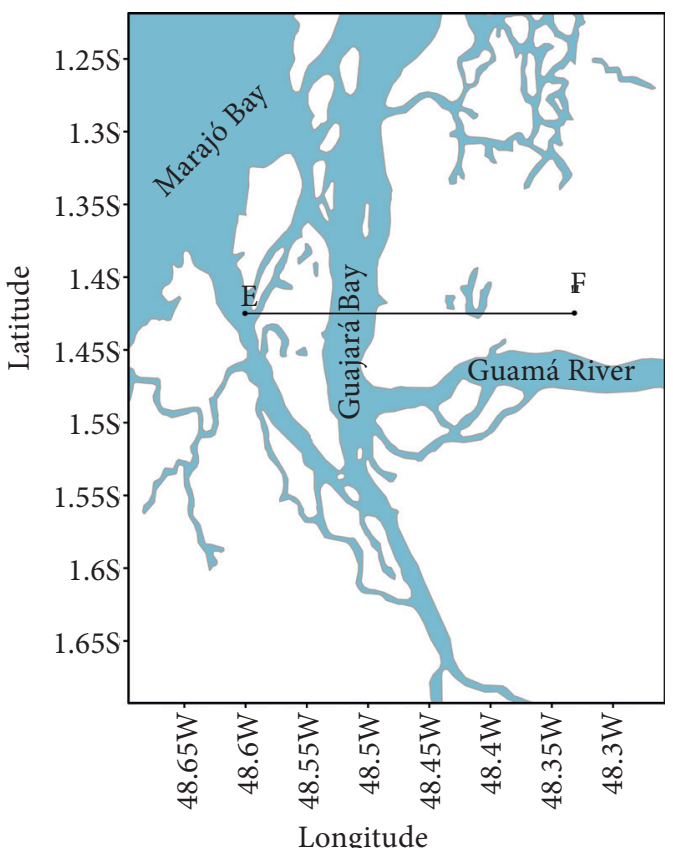

Figure 3. Transects analyzed in the simulations: $A B(a), C D(b)$, and $E F(c)$.

\section{RESULTS}

\section{MODEL EVALUATION AND SYNOPTIC CONDITIONS}

The satellite images show low-level cloudiness without deep clouds over the study region. In Fig. 4a, it is observed the presence of a Mesoscale Convective System (MCS) on the Eastern part of State of Amapá, possibly associated with the presence of Intertropical Convergence Zone (ITCZ) in this region. This system weakens at 08 UTC (Fig. 4b). On the continent, mostly low-level cloudiness 
is verified (Figs. 4a and 4b), especially in State of Pará. At 14 UTC (Fig. 4c), the conditions over the continent remain with a little cloud cover. At 20 UTC (Fig. 4d) we observe nuclei of low-level cloudiness beginning to form on State of Pará coast. However, this cloudiness does not deepen in the consecutive hours, dissipating at 22 UTC (figure not shown).
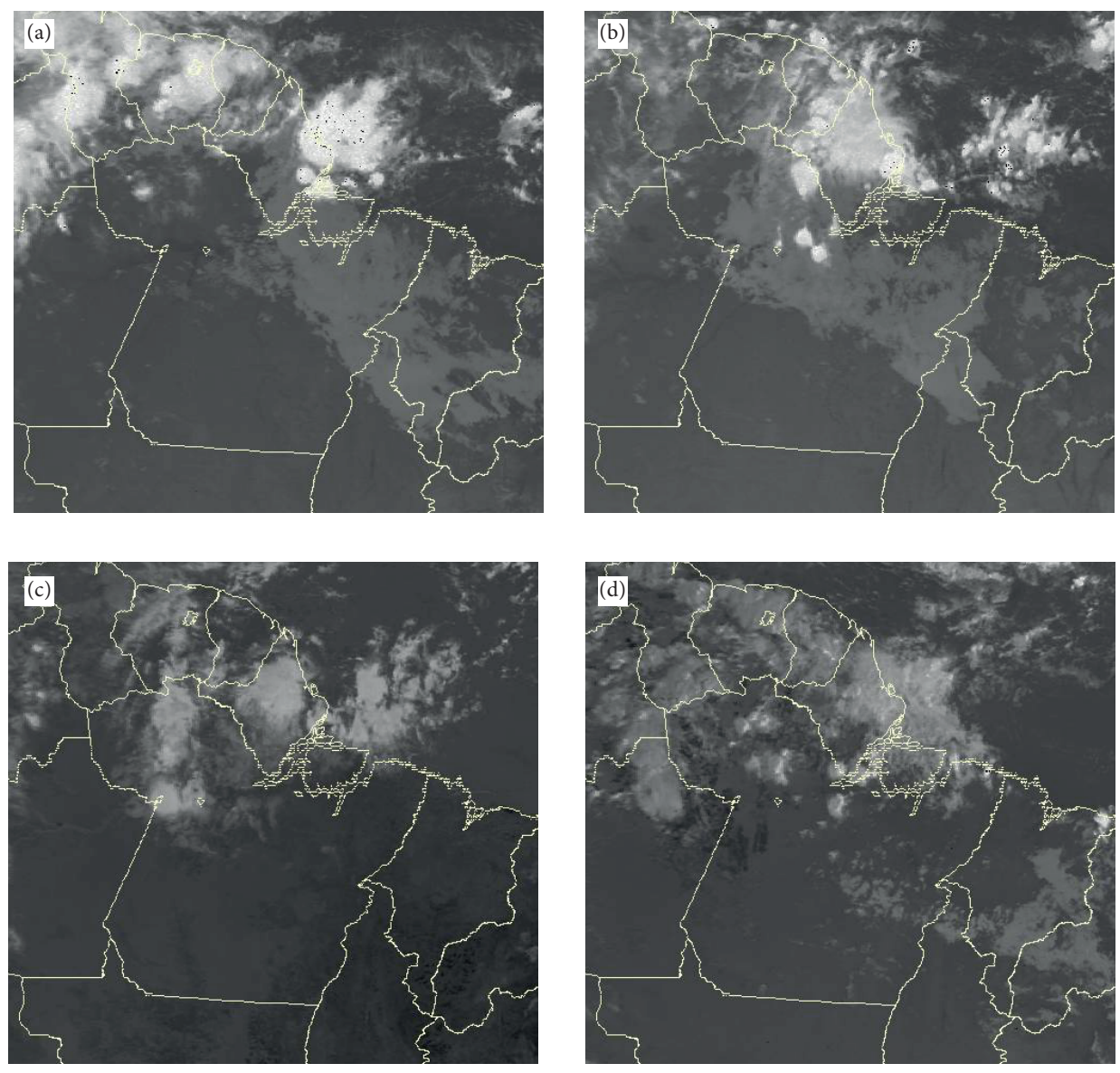

Figure 4. Satellite images for June $18^{\text {th }}, 2011$ on IR channel at 00 (a), 08 (b), 14 (c), and 20 (d) UTC.

Figure 5 shows the temporal evolution of wind direction and speed at the surface at different locations. In Belém (Fig. 5a), the observed data reveals an expressive rotation in surface wind at 18 UTC, associated with the onset of RB from Marajó Bay, which we renamed, for simplicity, as BB. This rotation is preceded by a decrease in the wind speed and then an increase along with the onset of $\mathrm{BB}$. For the wind direction, ERA 5 agrees with the observations of the onset of $\mathrm{BB}$, with some degrees of difference between observations and simulated values; WRF, in general, successfully gets the correct wind direction and onset of BB at all times. However, the wind speed (Fig. 5b) is overestimated by both WRF and ERA 5.

For Castanhal (Fig. 5c), both the model and ERA 5 represent the general behavior of the daily wind direction cycle. However, from 18-24 UTC until the next day, both ERA 5 and WRF present a slight deviation if compared to the observed data. It is also worth noticing that wind phase change, associated with breeze onset, in the series is slightly delayed if compared to the observed; wind rotation, associated with the onset of $\mathrm{BB}$, is delayed approximately $2 \mathrm{~h}$ in WRF compared to the observed. Matos and Cohen (2016) also find a delay in the formation of BB in BRAMS model. It is important to emphasize that Castanhal is at a point of juxtaposition between SB and BB. The observed data in Fig. $5 \mathrm{c}$ reveals that, at first, $\mathrm{BB}$ reaches its Northwest maximum (between 19 and 20 UTC), but then the flow gradually changes to North (between 20 and 24 UTC), signaling the onset of SB. The daily 
(a)

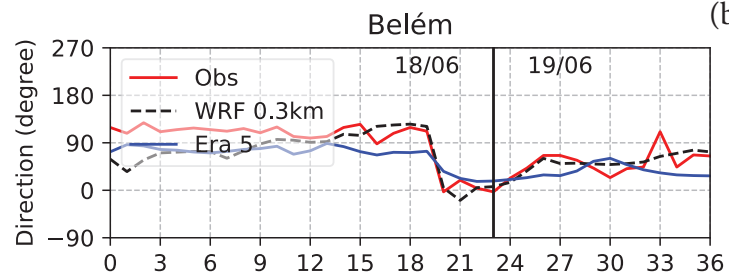

(c)

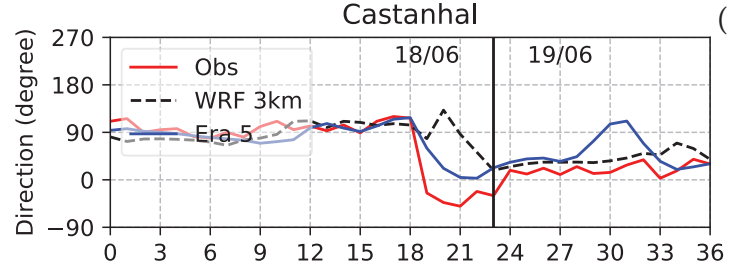

(e)

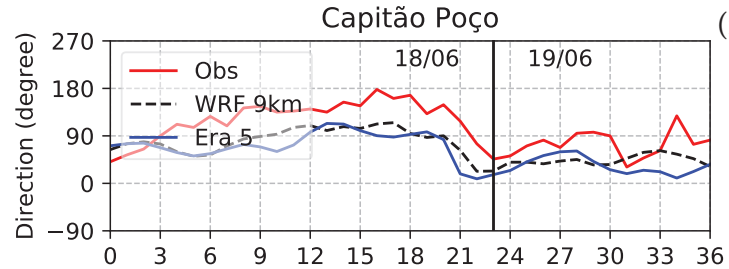

(g)

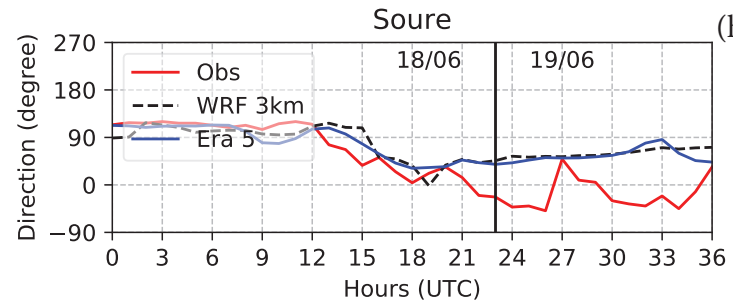

(b)

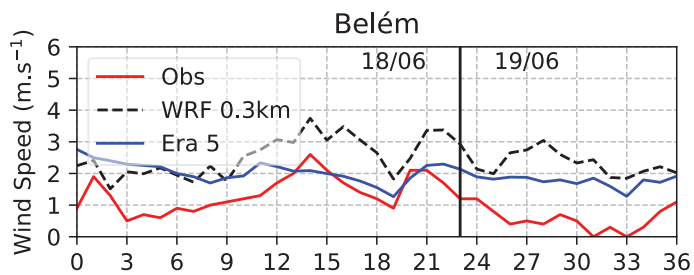

(d) Castanhal

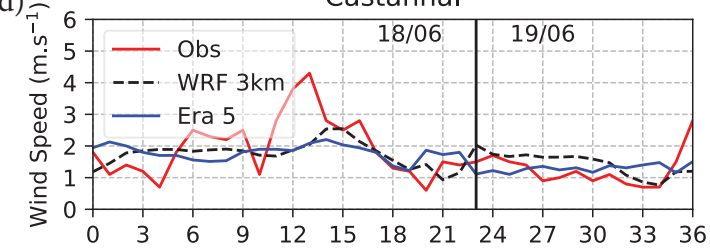

(f) न 6 Capitão Poço

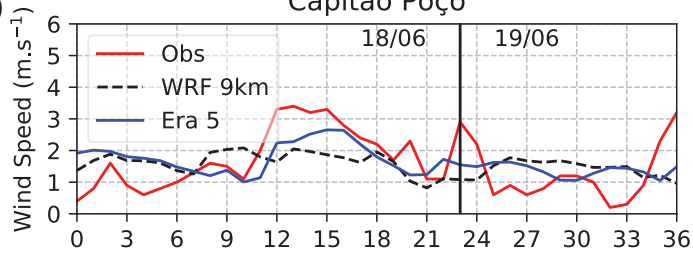

(h)

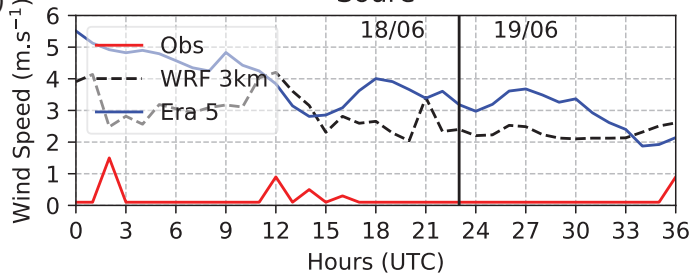

Figure 5. Wind direction and speed at $10 \mathrm{~m}$ for Belém (a and b), Castanhal (c and d), Capitão Poço (e and f), and Soure (g and h),

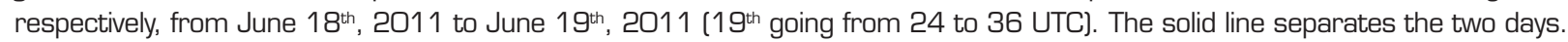

cycle of the wind speed (Fig. 5d) is represented by both WRF and ERA 5, although, between 11 and 13 UTC, they underestimate the maximum in wind speed. For Capitão Poço (Fig. 5e), the wind direction daily cycle is captured by both WRF and ERA 5, but with a performance slightly worse than in Belém; the wind speed daily cycle (Fig. 5f) for this locality is also captured. However, the maxima are generally underestimated for both wind direction and speed.

In Soure (Fig. $5 \mathrm{~g}$ ), it is verified that, during the first $12 \mathrm{~h}$ of the day, the wind presents an easterly flow; both ERA 5 and WRF captured the wind direction well in this period. At 15 UTC, the wind slowly changes its flow to North/Northeast, associated with the onset of SB, which is well captured by WRF and ERA 5. The observed data shows the presence of a LB (from 23 until 26 UTC), in the Northwestern direction, but this circulation is not captured by both the model and WRF. According to Germano et al. (2017) LB in Soure occurs in the Northwest direction due to its geographical position in relation to the adjacent water bodies. Wind speed (Fig. 5h) in Soure shows to have been overestimated by both WRF and ERA 5. Furthermore, compared to other locations, Soure presented the smallest observed wind speed.

Figure 6 displays that, for the four localities, the diurnal cycle of temperature was well-captured by the model. Although the overall performance of the model is good, the temperature maxima is not well-represented by both ERA 5 and WRF. It also can be observed that, among the four studied locations, Soure (Fig. 6d) presented the smallest thermal amplitude, which could probably be associated with its proximity to the coast, and thus it does not have high wind speed and thermal amplitude as found in the other localities. Although ERA 5 captured well the diurnal cycle of temperature for the majority of stations, the temperature diurnal cycle for Soure was not captured. In WRF simulation at 16 UTC, it is possible to observe a temperature drop in Soure, which may be related to a precipitation event. 
The overall performance of the model can be evaluated by calculating the following error statistics: RMSE, mAE, and mE, which values are given in Table 2. The statistical analyses show that the model's performance was good. RMSE for wind direction evidences that the model, on average, overestimated the wind direction by $40^{\circ}$ for all localities. Among the four locations analyzed, the model was able to predict better the wind direction for Soure, followed by Belém. It is worth mentioning that, in Soure, the $\mathrm{mE}$ was lower than $10^{\circ}$, showing a good performance. However, for the wind speed, Soure presented the worst performance among
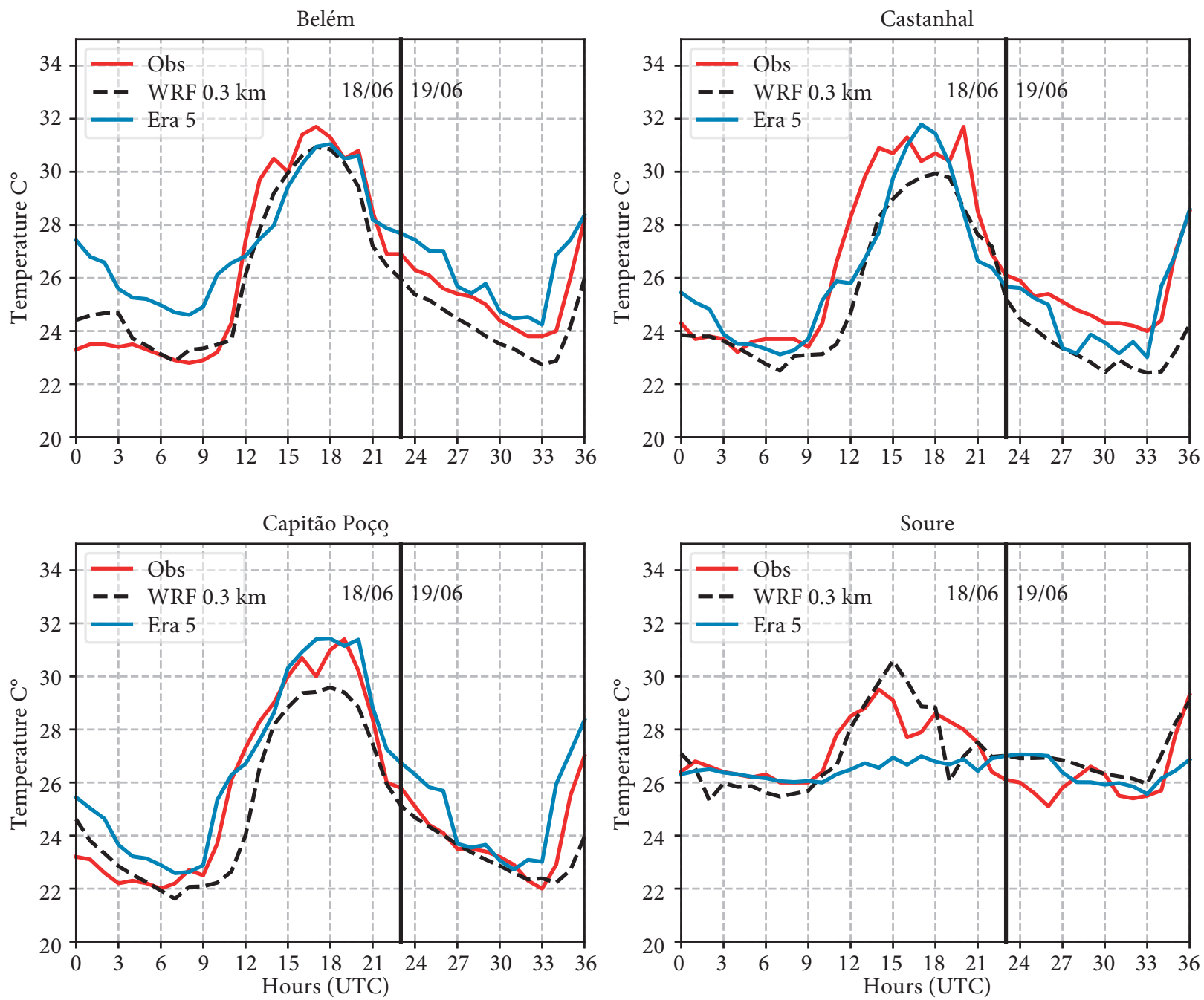

Figure 6. Same as Fig. 5, for temperature at $2 \mathrm{~m}$.

Table 2. Error statistics for each locality in June $18^{\text {th }}$, 2011.

\begin{tabular}{|c|c|c|c|c|c|c|c|c|c|}
\hline & \multicolumn{3}{|c|}{ Wind Direction } & \multicolumn{3}{c|}{ Wind Speed } & \multicolumn{3}{c|}{ Temperature } \\
\hline Locality & RMSE & $\mathrm{mAE}$ & $\mathrm{mE}$ & RMSE & $\mathrm{mAE}$ & $\mathrm{mE}$ & $\mathrm{RMSE}$ & $\mathrm{mAE}$ & $\mathrm{mE}$ \\
\hline Belém & 35.56 & 28.77 & -21.86 & 1.26 & 1.18 & 1.18 & 0.90 & 0.73 \\
\hline Castanhal & 55.71 & 35.19 & 14.47 & 0.81 & 0.61 & -0.19 & 1.62 & 1.19 & -1.15 \\
\hline Capitão Poço & 46.96 & 43.88 & -39.06 & 0.93 & 0.77 & -0.18 & 1.38 & 1.07 \\
\hline Soure & 31.39 & 23.85 & 7.95 & 2.95 & 2.87 & 2.87 & 0.92 & 0.71 \\
\hline
\end{tabular}


the localities. On the other hand, the model presented a good performance for Castanhal and Capitão Poço, with errors less than $1 \mathrm{~m} . \mathrm{s}^{-1}$ for both RMSE and $\mathrm{mAE}$; $\mathrm{mE}$ for wind speed in these two locations was negative, with values of approximately $-0.2 \mathrm{~m} . \mathrm{s}^{-1}$. For temperature, RMSE was approximately $1.0^{\circ} \mathrm{C}$, on average, for the four locations, and both $\mathrm{mAE}$ and $\mathrm{mE}$ were less than $1{ }^{\circ} \mathrm{C}$. Among the locations, the model was able to better predict the temperature for Soure, with an $\mathrm{mE}$ of $-0.09^{\circ} \mathrm{C}$. These values demonstrate that the performance of the model was relatively good in the localities analyzed in this study.

\section{REAL CASE ANALYSIS}

Figure 7 shows the wind at $10 \mathrm{~m}$ and temperature at $2 \mathrm{~m}$ for the different domains analyzed. At 00 UTC, in the Northeastern region of the domain (Fig. 7a), a southeasterly flow associated with LB can be noticed; however, this flow has low magnitude. It is also observed a temperature gradient between the ocean and the coast of approximately $3^{\circ} \mathrm{C}$. In the other domains (Figs. $7 \mathrm{~d}$, g), the wind shows a northeasterly flow without much variation in temperature.

In Fig. 7b, at 15 UTC, it is shown the onset of SB on the coast. It can be noticed that SB advects cold air from the ocean to the continent, forming a zone of convergence with continental flow, associated with the breeze front. In the other domains (Fig. 7e, h), there is also a significant temperature gradient between the water bodies and the continent, gradient which is one of the main mechanisms for formation of local circulations. According to Simpson (1994), a gradient of $1{ }^{\circ} \mathrm{C}$ is enough to form an SB in some regions. It is worth mentioning the presence of a fan-shaped circulation at the entrance of Guajará Bay (red circle on Fig. 7e). According to Santos (2015), many nautical accidents have been reported in this region related to big waves, which could happen due to this circulation pattern, since many embarkations sail in this specific region.

At 20 UTC (Fig. 7c), it is seen with more clarity the formation of the SB front and the advection of cold air promoted by SB. This SB front converges with an easterly continental flow. It can be noticed that SB propagates in different speeds on Marajó Island and Northeastern coast. The SB that propagates on Marajó Island advances with an approximately $0.2^{\circ}$ delayed if compared to the $\mathrm{SB}$ on Northeastern coast. Fig. $7 \mathrm{f}$ shows the onset of BB, initiated by SB, which is channelized through Marajó Bay, then forming BB. Fig. 6i displays that BB converges with a southerly flow near Belém, forming a BB front.

Figure 8 shows vertical cross-sections for transects $A B$ and $A F$. In transect $A B$, it can be observed low temperatures in the first kilometer of the atmosphere from 19 to 36 UTC (Fig. 8a) of the following day. The meridional component of the wind (Fig. 8c) reveals that, between 0 and $0.8 \mathrm{~km}$ in the atmosphere, for the same period (between 19 and 36 UTC), there is a phase change of the wind to the North (negative), indicating the onset of SB. Between 1 and $2.2 \mathrm{~km}$, it is noticed wind from the South (positive), just above SB, possibly associated with a return current embedded in the mean flow, with a maximum (hatched) at 23 UTC. It is possible to notice that, between 1 and 3 UTC, the flow on surface comes from the South (positive), possibly indicating the presence of an LB. Before the onset of SB, the vertical velocity (Fig. 8e) is shown to present positive values between 17 and 20 UTC, associated with the convection in the region of the breeze front. Wakimoto and Atkins (1994) show, in their study, the development of convection in the breeze front, ahead of the cold air advected by SB. These results converge with those found for the region, with the convection beginning approximately $2 \mathrm{~h}$ earlier than the onset of SB.

In transect $\mathrm{EF}$, it is seen that, similarly to transect $\mathrm{AB}$, there is an advection of cold air during the onset of $\mathrm{BB}$, at approximately 20 UTC, which is clear when analyzing the potential temperature profile (Fig. 8b) from lower temperatures with the onset of BB. It is verified that, in the vertical profile for the variable meridional wind (Fig. 8d), BB has an average height of approximately $0.7 \mathrm{~km}$ starting at 21 UTC with a northerly flow (negative); above this circulation, between 0.9 and $2.4 \mathrm{~km}$, we observe a southerly flow (positive), possibly associated with a return current, similarly to what was found in the SB case (Fig. 8c), with a maximum between 25 and 32 UTC. Between 18 and 20 UTC, another circulation is verified, with lower intensity and height, confined between 0 and $0.5 \mathrm{~km}$ with a southerly flow (positive), and a return current between 0.6 and $1.5 \mathrm{~km}$ with a northerly flow (negative), possibly associated with the RB from Guamá River. At 21 UTC, these two circulations converge, forming a region of intense convection, as shown in the vertical velocity profile (Fig. 8f), with a maximum height of $1.5 \mathrm{~km}$.

In transect CD (Fig. 9), it is possible to observe BB with more clarity. At the onset of BB (approximately 20 UTC), it is noticed that the potential temperature has a slight decrease (Fig. 9a), accompanied by a phase change in the meridional wind component at 21 UTC with a northerly flow (Fig. 9b). Around the onset of BB, it is seen a convection associated with BB front is observed, 
(a)

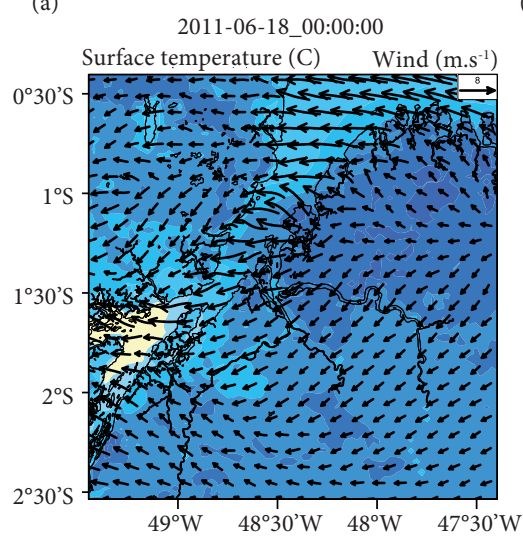

(d)

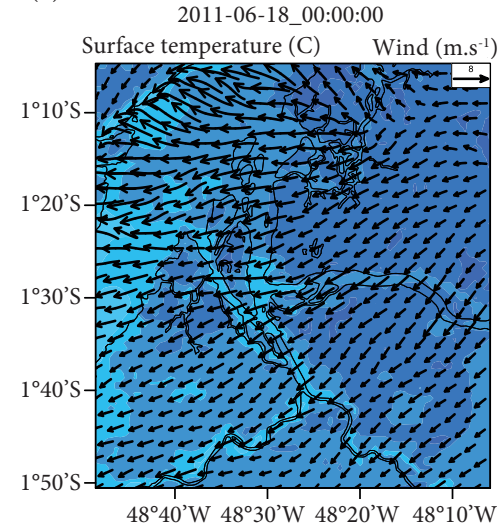

(g)

2011-06-18_00:00:00

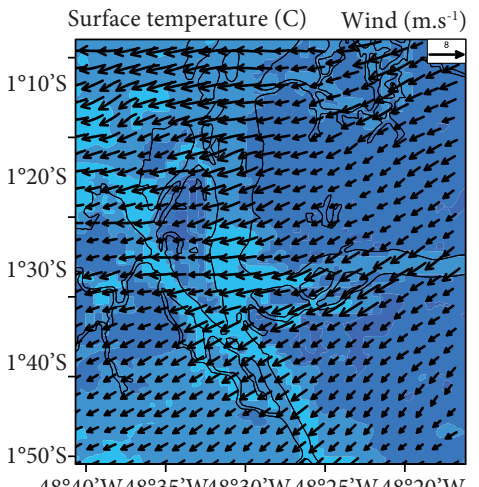

(b)

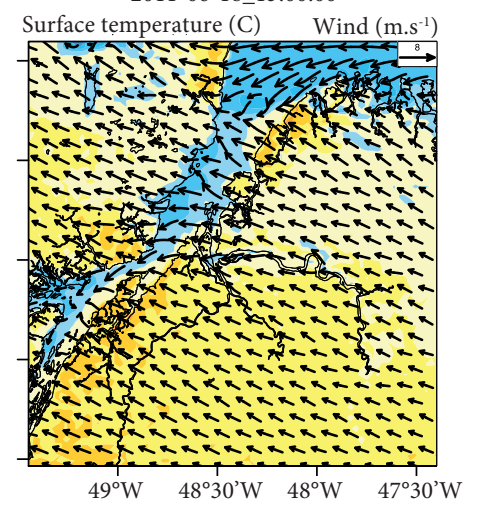

(e)

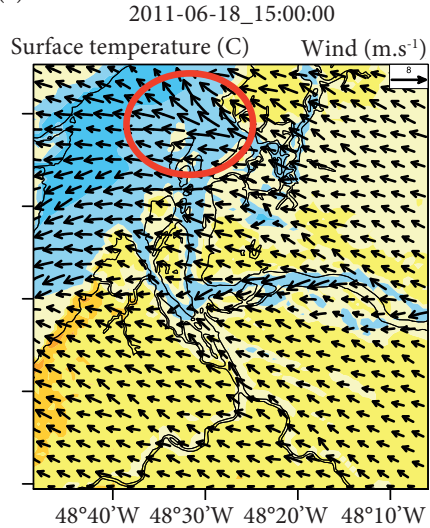

(h)

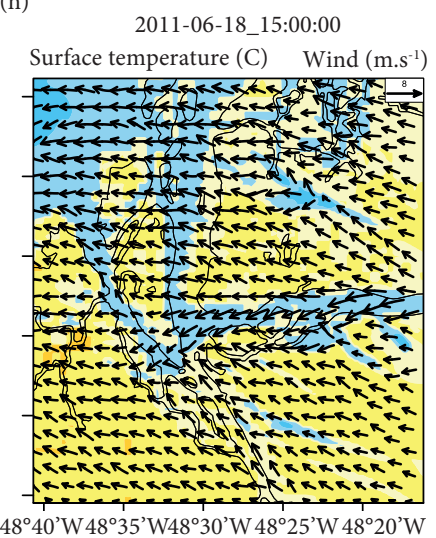

(c)

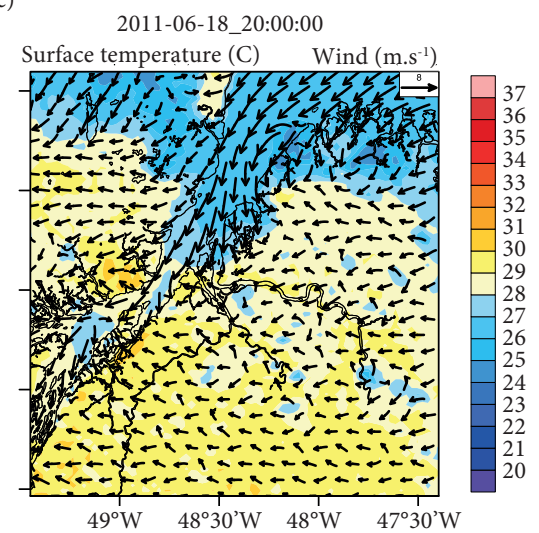

(f)

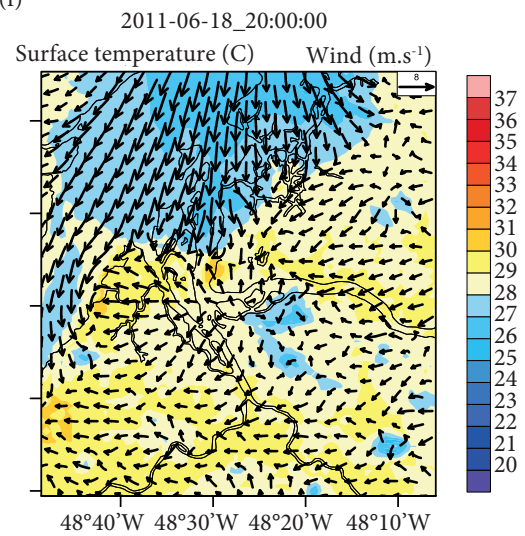

(i)

2011-06-18_20:00:00

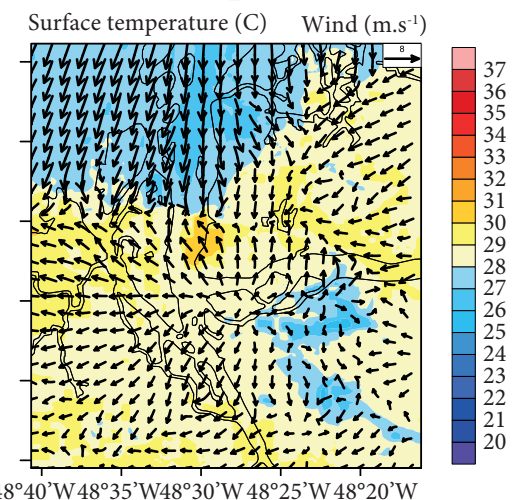

Figure 7. Potential temperature at $2 \mathrm{~m}$ and horizontal wind at $10 \mathrm{~m}$ in June $18^{\text {th }}, 2011$ in domains 2 (a, b, c), 3 (d, e, f] and $4(\mathrm{~g}, \mathrm{~h}, \mathrm{i})$ at $\mathrm{OO}(\mathrm{a}, \mathrm{d}, \mathrm{g}), 15(\mathrm{~b}, \mathrm{e}, \mathrm{h})$, and $2 \mathrm{O}(\mathrm{c}, \mathrm{f}, \mathrm{i})$ UTC. The red circle highlights the location of the fan-shaped circulation.

starting at 19 UTC (Fig. 9c). BB starts at approximately 21-20 UTC, with a height of approximately $0.7 \mathrm{~km}$. A possible return current is observed, highlighted by a maximum (hatched) in the meridional wind component of the wind, between 24 and 32 UTC, but also embedded in the mean flow, similar to the SB case. It can also be observed that this circulation extends until the next day, at approximately 34 UTC. 

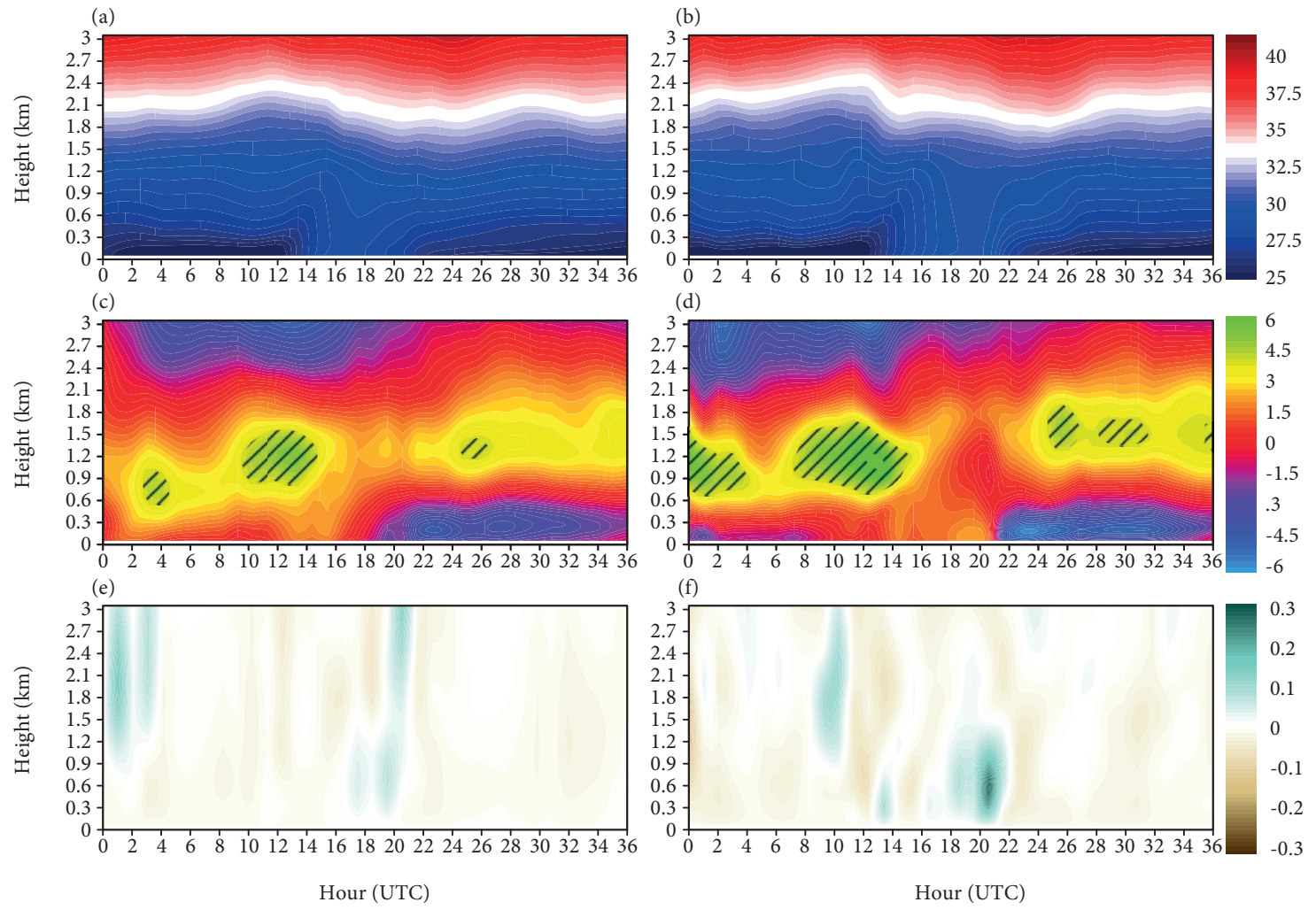

Figure 8. Temporal evolution along transects $A B$ (right) and EF (left) for potential temperature (a, b), meridional wind (c, d), and vertical velocity $(e, f)$. The hatched areas represent maximum values from 4.5 to $6 \mathrm{~m} . \mathrm{s}^{-1}$ in the meridional component of the wind.
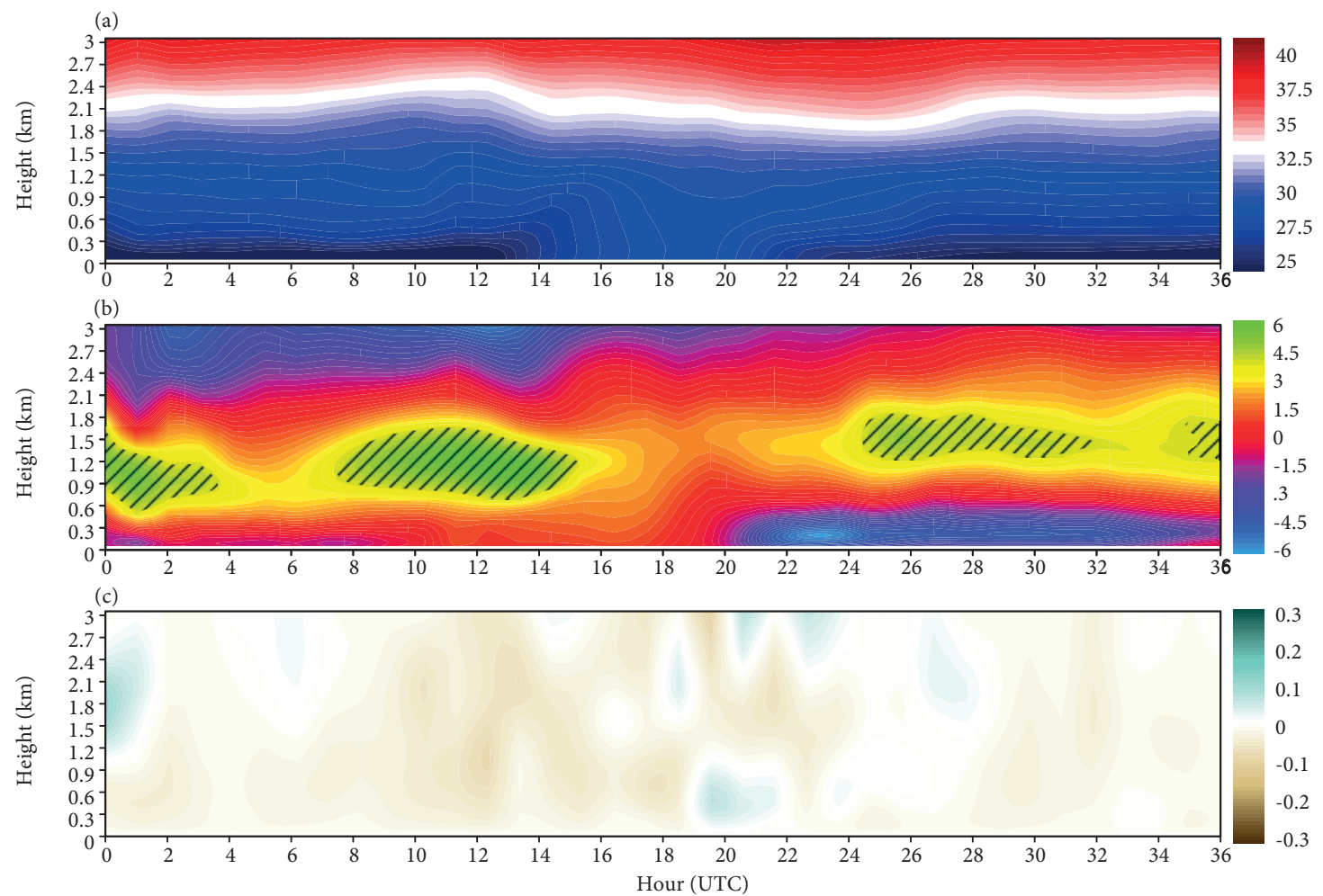

Figure 9. Temporal evolution along transect CD for potential temperature (a), meridional wind (b), and vertical velocity (c). The hatched areas represent maximum values from 4.5 to $6 \mathrm{~m} . \mathrm{s}^{-1}$ in the meridional component of the wind. 
Figure 10 depicts a vertical cross-section for transects $\mathrm{AB}$ and $\mathrm{EF}$. It is observed, in transect $\mathrm{AB}$, that $\mathrm{SB}$ is evident from approximately $48.6^{\circ} \mathrm{W}$ and $48.8^{\circ} \mathrm{W}$ (Fig. 10c). The potential temperature (Fig. 10a) reveals that the lowest temperatures are located in the regions where we have northerly flow maxima between $48.2^{\circ} \mathrm{W}$ and $48^{\circ} \mathrm{W}$. It is also worth noticing that, near $48.3^{\circ} \mathrm{W}$, there is a maximum in vertical velocity (Fig. 10e), which exceeds $3 \mathrm{~km}$ and is related to the SB channeling effect that occurs on Marajó Bay. Matos and Cohen (2016) detected the same channeling effect of the wind on Marajó Bay.

Transect EF reveals a Southern flow from Guamá River (Fig. 10d). The southern flow (positive) shows to be concentrated between the surface up to $0.3 \mathrm{~km}$. The return current of this circulation is clear, with the maximum from North (negative) between $48.5^{\circ} \mathrm{W}$ and $48.4^{\circ} \mathrm{W}$, located vertically between $0.6 \mathrm{~km}$ and $1.2 \mathrm{~km}$. In the region that this circulation occurs, maximum values of vertical velocity (Fig. 10f) are reported. This circulation has a lower intensity compared to SB or BB, without cold air advection (Fig. 10b).

Figure 11a displays that cold air advection during the onset of $\mathrm{BB}$ is evident, marked by wind from North (negative) and its return current (Fig. 11b). This circulation is most intense between $1.32^{\circ} \mathrm{S}$ and $1.17^{\circ} \mathrm{S}$. It is also possible to verify with clarity the circulation on Guamá River, with wind from the South on the surface up to $0.3 \mathrm{~km}$ and a return current with wind from the North. It is noticed that the exact location of the merge of vertical velocity (Fig. 11c) between BB circulation and the circulation from Guamá River is at between $1.45^{\circ} \mathrm{S}$ and $1.42^{\circ} \mathrm{S}$, with maximum values of $1.5 \mathrm{~m} . \mathrm{s}^{-1}$.

\section{OBSERVATIONS IN BELÉM}

To confirm the existence of the new circulation found in Belém (from Guamá River), the anomaly of the zonal and meridional wind for Belém was computed for the period from 2003 to 2013. During the first hours of the day (between 0 and 13 UTC), the meridional wind is shown to be weak (Fig. 12a). Between April and September, in the interval from 14 to 17 UTC, there is a southerly flow (positive) in Belém, associated with Guamá River breeze. It can also be noticed that this southerly flow has greater

(a)
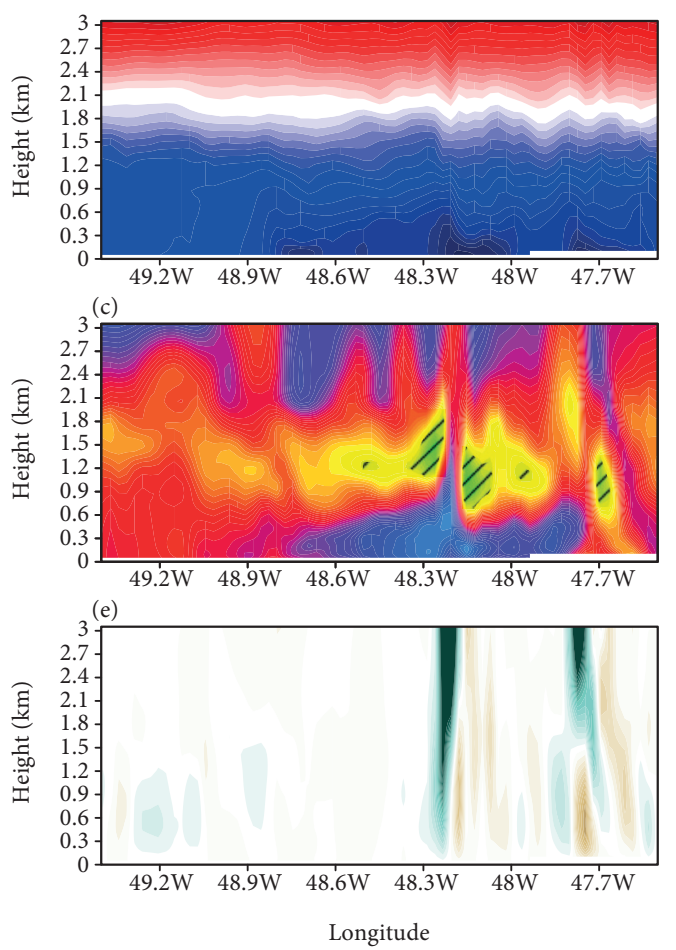

(b)
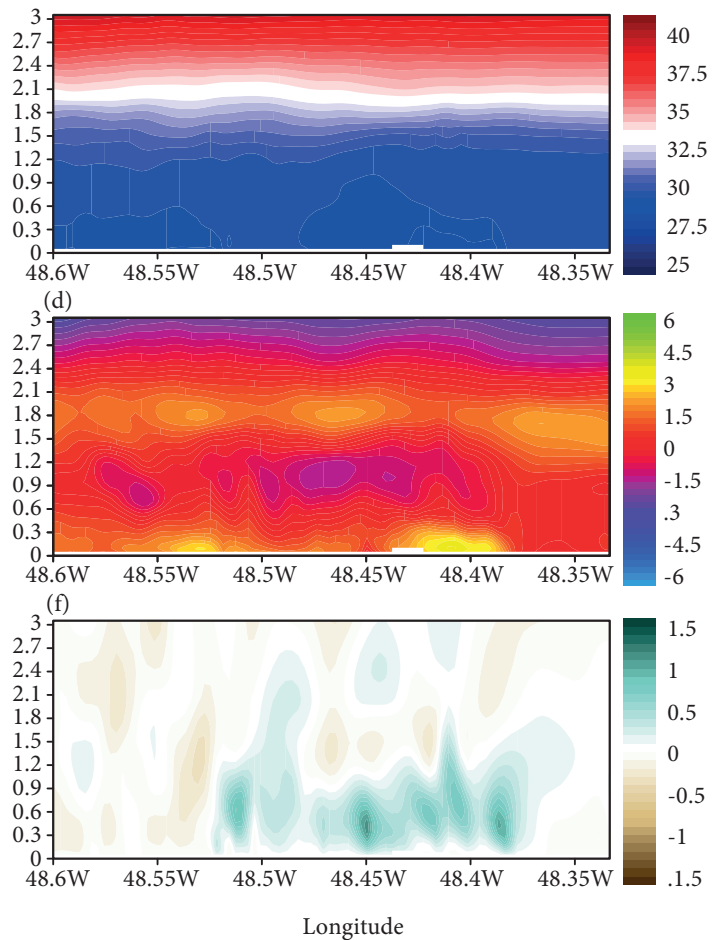

Figure 10. Vertical cross-section at 20 UTC for transects AB (left) and EF (right) for the variables potential temperature $(a, b)$, meridional wind $(c, d)$, and vertical velocity $(e, f)$. The hatched areas represent maximum values from 4.5 to $6 \mathrm{~m} . \mathrm{s}^{-1}$ in the meridional component of the wind. 

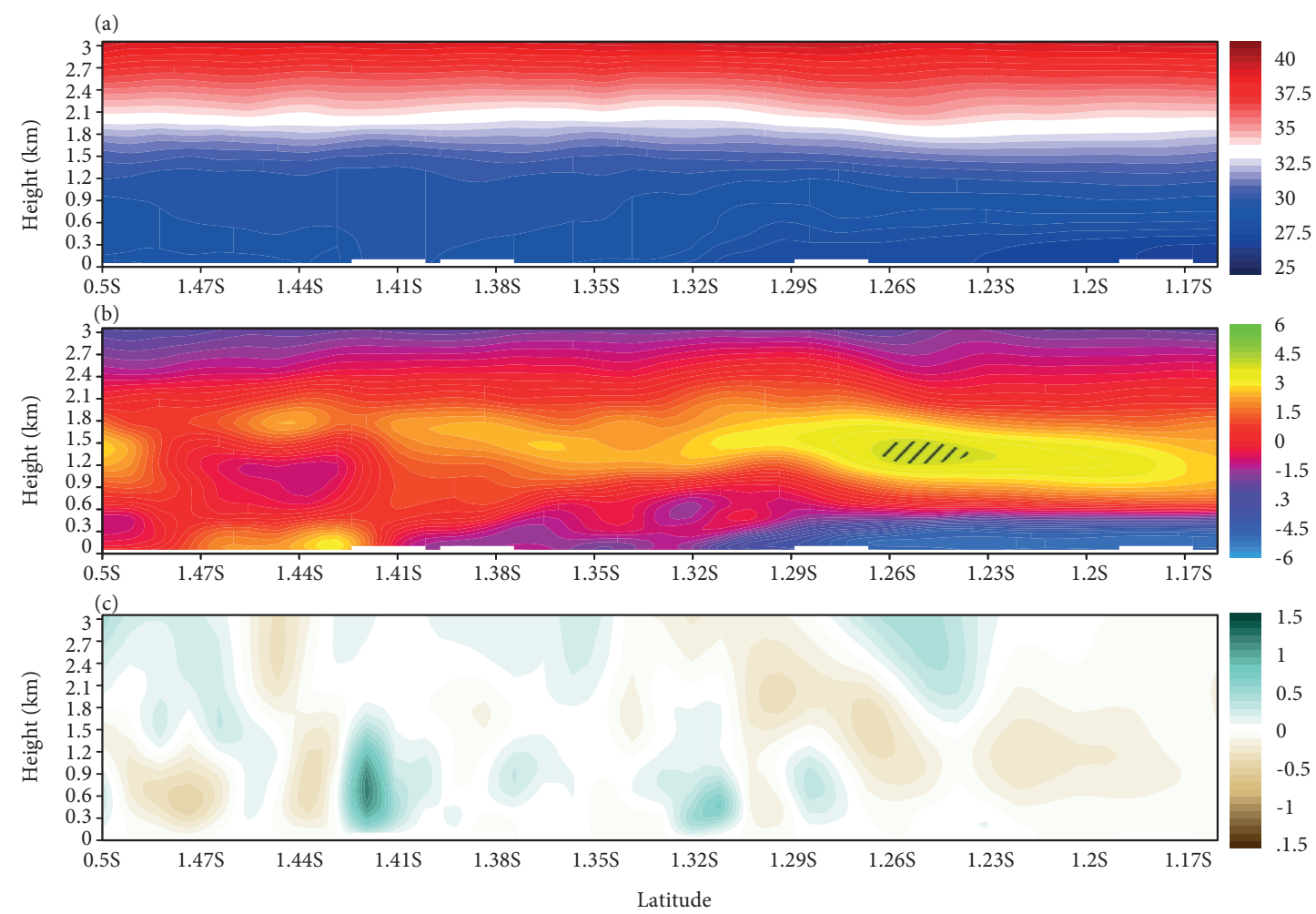

Figure 11. Vertical cross-section at 20 UTC for transect CD for the variables potential temperature (a), meridional wind (b), and vertical velocity (c). The hatched areas represent maximum values from 4.5 to $6 \mathrm{~m}^{-\mathrm{s}^{-1}}$ in the meridional component of the wind.
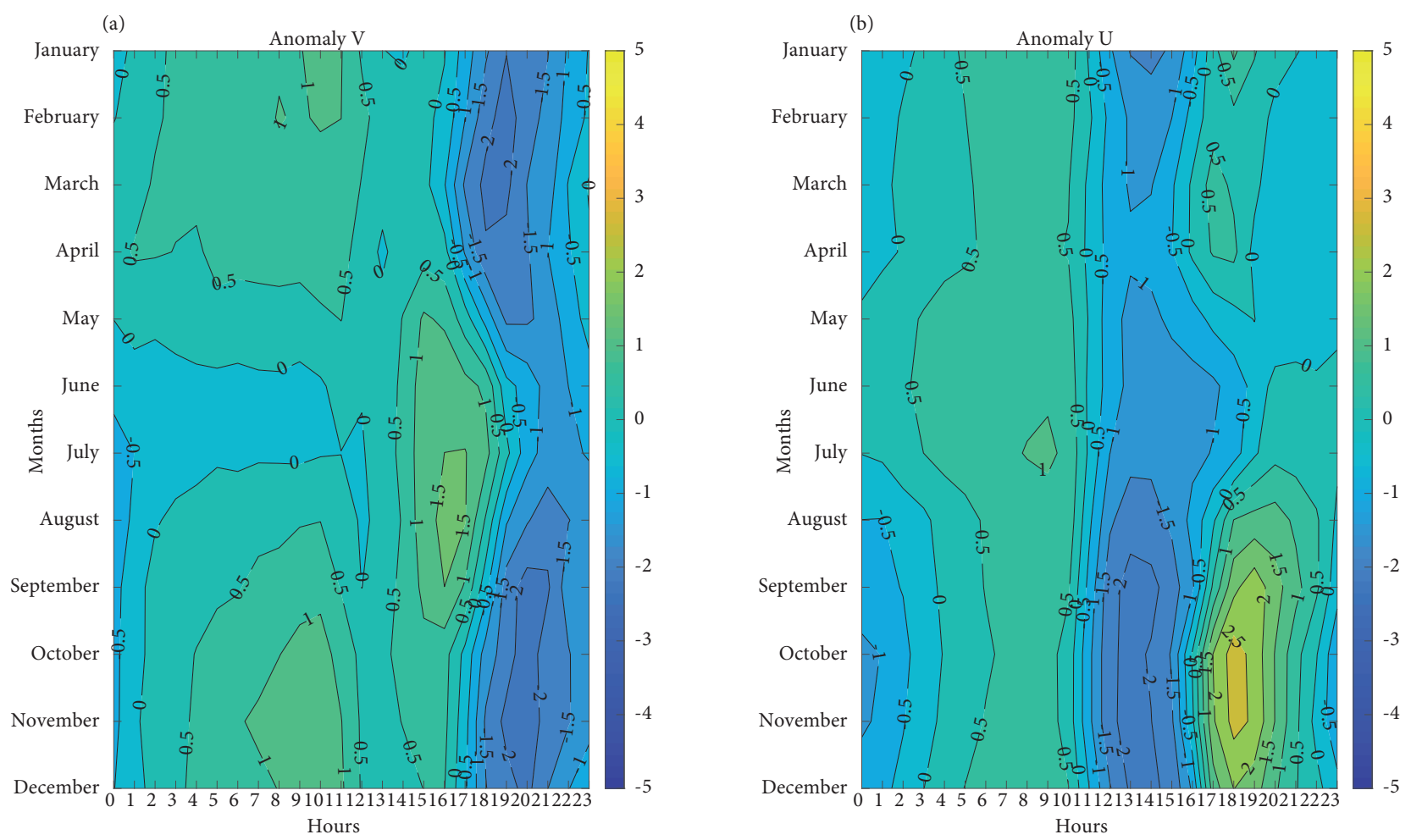

Figure 12. Monthly hourly anomaly for meridional (a) and zonal (b) wind component from 2003 to 2013 in Belém. 
intensity between the months of July and September, the dry period in the region. At 18 UTC, a phase change from South to North is observed, associated with the onset of BB. This northerly flow shows to be predominant during the whole year, which agrees with the results found by Germano et al. (2017). The onset of BB and Guamá River breeze showed a delay of 4 h for Guamá River breeze and $2 \mathrm{~h}$ for $\mathrm{BB}$ if compared to the simulation.

When the zonal component of the wind is analyzed (Fig. 12b), it is verified that, between 0 and 10 UTC, the wind presents low intensity. However, between 10 and 16 UTC, the wind has an easterly flow. At 17 UTC, there is a phase change associated with the onset of BB, extending until 22 UTC. It is also observed that BB has greater intensity between the months of September and November, again agreeing with the results of Germano et al. (2017).

Although BB has already been identified by Germano et al. (2017), the presence of Guamá River breeze was not mentioned. Wanzeler (2018) cites a southwesterly circulation, which the author attributes to local and/or regional factors. The difficulty in identifying this circulation is due its lower intensity, being suppressed by the sign of BB. However, with the results found in simulations and observations by calculating the anomaly, the southeasterly circulation from Guamá River is evident, being an important circulation for the city of Belém.

\section{CONCLUSIONS}

A real case simulation was analyzed in order to identify the local circulations and its features in Eastern Amazon. To this end, we simulated in high-resolution a case (June $18^{\text {th }}, 2011$ ) with low interference of synoptic weather systems and precipitation, in order to eliminate the effects of convective systems in local circulations. We also evaluated model performance for the day studied and confirmed, through observational data, the existence of the circulations found in the simulation.

In summary, the model was able to capture most of the circulation patterns for the studied area. The wind direction and speed are well-represented, except for the maxima, which are generally not well-represented in the wind speed. The model has also shown a delay in BB onset of approximately $2 \mathrm{~h}$ in Castanhal, which was also observed by Matos and Cohen (2016). Regarding the temperature at the surface, the diurnal cycle was well represented by the model for the four localities studied. However, Soure presented a different pattern, which the model was able to capture while ERA 5 did not.

The simulation revealed the presence of three main circulations:

1. SB on the coast with a northeasterly flow;

2. A southeasterly flow, near the coast, associated with LB;

3. $\mathrm{BB}$, which is first initiated by SB and then channelized through Marajó Bay, forming then BB on both banks of said bay.

SB is clear between the surface up to $0.8 \mathrm{~km}$, starting at 19 UTC; its onset is marked by a phase change in the meridional wind component from South to North. Furthermore, this circulation showed a possible return current, embedded in the mean flow. On the other hand, it was found a signal associated with LB between 1 and 3 UTC, with a lower magnitude compared to SB. BB has an average height of approximately $0.7 \mathrm{~km}$ (about $100 \mathrm{~m}$ shallower than SB) and starts at $21 \mathrm{UTC}$. This circulation has a return current between 0.8 and $2.4 \mathrm{~km}$, with a southerly flow. The circulations found in the simulation agree with the observational study made by Germano et al. (2017) for the region.

On a smaller scale, the presence of a RB from Guamá River, located to the South of Belém, was found. This circulation has its genesis at 18 UTC and has its signal suppressed by BB at 20 UTC, being shallower than SB and BB, with an average height of $0.5 \mathrm{~km}$, and having its return current confined between 0.6 and $1.5 \mathrm{~km}$ with a northerly flow. At 21 UTC, the RB from Guamá River converges with the $\mathrm{BB}$, forming a region of intense convection. The observations confirmed the presence of this circulation, which is more active between July and September. Both BB and Guamá River breeze showed a delay of some hours if the model simulations were compared to the observations. 
Another important feature found in the simulation was the presence of a fan-shaped circulation formed at the entrance of Guajará Bay. Ezber et al. (2015) found a similar circulation at the outlet of Bosphorus channel, in Istanbul, Turkey.

\section{FUNDING}

Coordenação de Aperfeiçoamento de Pessoal de Nível Superior

[https://doi.org/10.13039/501100002322]

\section{AUTHORS' CONTRIBUTION}

All authors contributed equally to this paper.

\section{REFERENCES}

Beljaars ACM (1995) The parametrization of surface fluxes in large-scale models under free convection. Q J R Meteorol Soc 121(522): 255-270. https://doi.org/10.1002/qj.49712152203

Clarke GM, Cooke D (1978) A basic course in statistics. Vol. 406. New York: Arnold.

Dudhia $J$ (1989) Numerical study of convection observed during the winter monsoon experiment using a mesoscale two-dimensional model. J atmos sci 46(20):3077-3107. https://doi.org/10.1175/1520-0469(1989)046<3077:NSOCOD>2.0.C0;2

Dyer AJ, Hicks BB (1970) Flux-gradient relationships in the constant flux layer. Q J. R Meteorol Soc 96(410):715-721. https:// doi. org/10.1002/qj.49709641012

Ezber Y, Sen OL, Boybeyi Z, Karaca M (2015) Investigation of local flow features in Istanbul. Part I: high-resolution sensitivity simulations. Int J Climatol 35(13):3812-3833. https://doi.org/10.1002/joc.4248

Germano MF, Vitorino MI, Cohen JCP, Costa GB, Souto JIDO, Rebelo MTC, de Sousa AML (2017) Analysis of the breeze circulations in Eastern Amazon: An observational study. Atmos Sci Lett 18(2): 67-75.

Hersbach H, Dee D (2016) ERA5 reanalysis is in production. ECMWF newsletter 147(7).

Hong SY, Juang HMH, Zhao Q (1998) Implementation of prognostic cloud scheme for a regional spectral model. Mon Weather Rev 126(10):2621-2639. https://doi.org/10.1175/15200493(1998)126<2621:IOPCSF>2.0.C0:2

Hong SY, Dudhia J, Chen SH (2004) A revised approach to ice microphysical processes for the bulk parameterization of clouds and precipitation. Mon Weather Rev 132(1):103-120. https://doi.org/10.1175/15200493(2004)132<0103:ARATIM>2.0.CD:2

Hong SY, Noh Y, Dudhia J (2006) A new vertical diffusion package with an explicit treatment of entrainment processes. Mon Weather Rev 134(9):2318-2341. https://doi.org/10.1175/MWR3199.1

Kain JS (2004) The Kain-Fritsch convective parameterization: an update. J Appl Meteorol 43(1):170-181. 10.1175/1520-0450(2004)04360;0170:tkcpau62;2.0.co;2

Lu L, Denning AS, Silva-Dias MAF, Silva-Dias PL, Longo M, Freitas SR, Saatchi S (2005) Mesoscale circulations and atmospheric CO2 variations in the Tapajós Region, Pará, Brazil. J Geophys Res. Atmospheres 110(D21). https://doi.org/10.1029/2004JD005757

Matos AP, Cohen JCP (2016) Circulação de brisa e a banda de precipitação na margem leste da baía de Marajó. CeN 38:21-27. https:// doi.org/10.5902/2179460X19814

Miller STK, Keim BD, Talbot RW, Mao H (2003) Sea breeze: Structure, forecasting, and impacts. Rev Geophy 41(3). https://doi. org/10.1029/2003RG000124 
Mlawer EJ, Taubman SJ, Brown PD, lacono MJ, Clough SA (1997) Radiative transfer for inhomogeneous atmospheres: RRTM, a validated correlated-k model for the longwave. J Geophys Res. Atmospheres 102(D14):16663-16682. https://doi.org/10.1029/97JD00237

Guo-Yue N, Zong-Liang Y, Mitchell KE, Fei C, Ek MB, Barlage M, Kumar A, Manning K, Niyogi D, Rosero E et al. (2011) The community Noah land surface model with multiparameterization options (Noah-MP): 1. Model description and evaluation with local-scale measurements. $J$ Geophys Res. Atmospheres 116(D12). https://doi.org/10.1029/2010JD015140

Oliveira AP, Fitzjarrald DR (1993) The Amazon river breeze and the local boundary layer: I. Observations. Bound-Layer Meteorol 63(1):141162. https://doi.org/10.1007/BFO0705380

Oliveira AP, Fitzjarrald DR (1994) The Amazon river breeze and the local boundary layer: II. Linear analysis and modelling. Bound-Layer Meteorol 67(1):75-96. https://doi.org/10.1007/BF00705508

Oliveira FP (2017) Processos convectivos na iniciação de linhas de instabilidade na costa norte do Brasil (PhD thesis). São José dos Campos: Instituto Nacional de Pesquisas Espaciais. In portuguese.

Orlanski I (1975) A rational subdivision of scales for atmospheric processes. Bull Am Meteorol Soc 56(5):527-530.

Paulson CA (1970) The mathematical representation of wind speed and temperature profiles in the unstable atmospheric surface layer. $J$ Appl Meteorol 9(6):857-861. https://doi.org/10.1175/1520-0450(1970)009<0857:TMROWS>2.0.C0;2

Santos SHM (2015) Acidentes com transportes hidroviários e os extremos meteorológicos no nordeste da Amazônia (MSc dissertation). Belém: Universidade Federal do Pará. In portuguese.

Santos MJ (2017) Impact of the rivers and the seasonal flooding on the local climate of Central Amazon (PhD thesis). São Paulo: Universidade de São Paulo.

Silva-Dias MAF, Silva-Dias PL, Longo M, Fitzjarrald DR, Denning AS (2004) River breeze circulation in Eastern Amazonia: observations and modelling results. Theor Appl Climatol 78(1-3):111-121. https://doi.org/10.1007/s00704-004-0047-6

Simpson JE (1994) Sea breeze and local winds. Cambridge: Cambridge University Press.

Skamarock WC, Klemp J, Dudhia J, Gill DO, Barker D, Duda MG, Xiang-Yu H, Wei W, Powers JG (2008) A Description of the Advanced Research WRF Version 3.'NCAR Technical Note NCAR/TN-475+ STR. https://doi.org/10.5065/D68S4MVH

Souza DCD, Oyama MD (2017) Breeze potential along the Brazilian Northern and Northeastern coast. J Aerosp Technol Manag 9(3):368378. https://doi.org/10.5028/jatm.v9i3.787

Souza Filho PWM (2005) Costa de manguezais de macromaré da Amazônia: cenários morfológicos, mapeamento e quantificação de áreas usando dados de sensores remotos. Rev Bras Geof 23(4):427-435. https://doi.org/10.1590/S0102-261X2005000400006

Wakimoto RM, Atkins NT (1994) Observations of the sea-breeze front during CaPE. Part I: Single-Doppler, satellite, and cloud photogrammetry analysis. Mon Weather Rev 122(6):1092-1114. https://doi.org/10.1175/1520-0493(1994)122<1092:00TSBF>2.0.CO;2

Wanzeler RTS (2018) Períodos ativos e inativos da brisa nas regiões do Centro de Lançamento de Alcântara e de Belém/PA durante o período seco (MSc dissertation). São José dos Campos: Instituto Nacional de Pesquisas Espaciais. In portuguese.

Webb EK (1970). Profile relationships: The log-linear range, and extension to strong stability. Q J R Meteorol Soc 96(407):67-90. https://doi.org/10.1002/qj.49709640708

Wei W, Barker D, Bray J, Bruyere C, Duda M, Dudhia J, Gill D, Michalakes J (2007) User's guide for advanced research WRF (ARW) modeling system version 3. Mesoscale and Microscale Meteorology Division-National Center for Atmospheric Research (MMM-NCAR).

Zong-Liang Y, Guo-Yue N, Mitchell KE, Fei C, Ek MB, Barlage M, Longuevergne L, Manning K, Niyogi D, Tewari M, Youlong X (2011) The community Noah land surface model with multiparameterization options (Noah-MP): 2. Evaluation over global river basins. J Geophys Res. Atmospheres 116(D12). https://doi.org/10.1029/2010JD015140

Zhang D, Anthes RA (1982) A high-resolution model of the planetary boundary layer - Sensitivity tests and comparisons with SESAME-79 data. J Appl Meteorol 21(11):1594-1609. https://doi.org/10.1175/1520-0450(1982)021<1594:AHRMOT>2.0.C0;2 